\title{
Persepsi Diabaikan Orangtua Memicu Mahasiswa Bunuh Diri
}

\author{
Loora, Zainal Abidin \\ ${ }^{1}$ Progam Studi Magister Profesi Psikologi, Fakultas Psikologi, Universitas Padjadjaran \\ ${ }^{2}$ Fakultas Psikologi, Universitas Padjadjaran \\ Email: loora18001@mail.unpad.ac.id, zainal.abidin@unpad.ac.id
}

\begin{abstract}
Perceived rejected by parents trigger suicide ideation. The suicide rate is high in Indonesia, especially among undergraduate students. Suicidal behavior is a way of solving negative problems which can also be a measure of student mental health. This study seeks to find out more about the factors that cause commit suicide. This method is an indepth interview with three students who have suicidal ideation. The results of this study found several group factors in all subjects, namely dispotional vurnerability factors, generalization, additional stress, attention fixation, low stress tolerance threshold, and history of self-injury. It also found stress relieved from suicides with the perceived rejection. The threshold for tolerance to stress can be increased by a desire to achieve goals and an optimistic mind that the future will be better. Thus, suicidal ideation arises because of internal factors (maladaptive cognitive processes) and external factors (similar sources of stress).
\end{abstract}

Keywords: Cognitive Model of Suicidal Behavior, Perceived Rejection, Suicide Ideation.

\begin{abstract}
Abstrak. Angka bunuh diri tinggi di Indonesia terutama pada kalangan usia mahasiswa sarjana. Tingkah laku bunuh diri merupakan cara penyelesaian masalah negatif yang juga dapat menjadi ukuran kesehatan mental mahasiswa. Pada penelitian ini berfokus untuk menggali lebih mendalam faktor-faktor yang memicu tingkah laku bunuh diri timbul. Metode penelitian ini adalah in-depth interview terhadap tiga orang mahasiswa dengan suicide ideation (ide bunuh diri). Hasil penelitian ini menemukan terdapat beberapa faktor kesamaan pada seluruh subjek, yaitu dispotisional vulnerability factors, generalisasi, stres tambahan, fiksasi atensi, ambang toleransi stres yang rendah, dan riwayat self-harm. Ditemukan juga stres yang memicu bunuh diri berhubungan dengan persepsi pengalaman diabaikan atau disakiti (perceived rejection). Ambang toleransi terhadap stres tersebut dapat ditingkatkan dengan keinginan mencapai cita-cita dan pikiran optimis bahwa masa depan akan lebih baik. Dengan demikian ide bunuh diri muncul karena faktor dari dalam diri (proses kognitif yang maladaptif) dan faktor dari luar diri (sumber stress yang serupa).
\end{abstract}

Kata kunci: Ide bunuh diri, Model kognitif tingkah laku bunuh diri, Persepsi diri diabaikan.

\section{PENDAHULUAN}

Data terakhir World Health Organization (2015a), menunjukkan bunuh diri merupakan salah satu masalah kesehatan dunia yang perlu ditangani segera. WHO memperkirakan terjadi sekitar 788.000 tindakan bunuh diri pada tahun 2015. Selain itu, satu kasus bunuh diri dapat memicu 20 orang lainnya untuk melakukan percobaan bunuh diri (WHO, 2015). Sedangkan di Indonesia selalu terjadi kasus bunuh diri oleh mahasiswa warga Negara Indonesia (table 1). Kasus bunuh diri pada mahasiswa terjadi dari berbagai asal jurusan dan perguruan tinggi yang terkemuka di Indonesia. Mahasiswa yang melakukan completed suicide rata-rata mahasiswa program sarjana dengan rentang usia 19 hingga 24 tahun. Rata-rata tindakan bunuh diri tersebut dilakukan di kamar indekos yang berada disekitar kampus.

Tabel 1. Daftar Kasus Mahasiswa Bunuh Diri

\begin{tabular}{ccc}
\hline Tahun & $\begin{array}{c}\text { Jumlah } \\
\text { (orang) }\end{array}$ & Usia (tahun) \\
\hline 2014 & 2 & 23 dan 24 \\
\hline 2015 & 3 & 21 hingga 23 \\
\hline 2016 & 2 & 22 dan 24 \\
\hline 2017 & 1 & 21 \\
\hline 2018 & 4 & 22 hingga 24 \\
\hline 2019 & 5 & 19 hingga 23 \\
\hline
\end{tabular}

Tabel ini hanya berisi daftar mahasiswa yang bunuh diri dan diberitakan di media masa saja. Sedangkan untuk kasus bunuh diri yang ditutupi sebagai kasus pembunuhan dan kasus bunuh diri yang tidak diberitakan tidak dapat diperkirakan jumlahnya. Berdasarkan hasil wawancara singkat peneliti dengan salah seorang 
mantan konselor bunuh diri, ditemukan bahwa adanya kesamaan keluhan dari para kliennya (mahasiswa). Ditemukan ada kesamaan masalah yang bermula dari konflik dalam relasi dengan orang lain, seperti orangtua. Akibat konflik tersebut klien rata-rata merasa stress, kesepian, dan berpikir untuk bunuh diri. Temuan ini juga sejalan dengan hasil wawancara peneliti dengan salah seorang mahasiswa yang memiliki suicide ideation dan/ suicide attempts.

Dari hasil wawancara awal dengan 3 orang narasumber, ada beberapa tema yang muncul yaitu merasa diabaikan atau terisolasi oleh orang yang signifikan bagi narasumber, merasa putus asa atau hopeless, hanya memiliki satu cara coping dan kurang tepat, ada usaha mencari bantuan orang sekitar atau tenaga profesional, merasa lebih baik mati dari pada menderita terus-menerus, memiliki pengalaman kehilangan orang yang signifikan bagi narasumber, dan berusaha memperbaiki hubungan dengan signifikan bagi narasumber. Tema yang paling menonjol yang memicu pikiran untuk bunuh diri yaitu merasa diabaikan atau terisolasi oleh orang dewasa yang signifikan bagi narasumber berdasarkan pengalaman dan hanya memiliki satu cara coping yang kurang efektif. Sedangkan tema yang menjadi faktor protektif narasumber dari tindakan bunuh diri yaitu ada usaha untuk memperbaiki masalah hubungan dengan signifikan bagi narasumber dan usaha mencari bantuan orang sekitar atau tenaga profesional.

Penelusuran awal peneliti sejalan dengan hasil penelitian Brown, Mitchell, Rousch, Rosa, dan Cukrowicz (2019) yang menjelaskan bahwa hubungan interpersonal atau keterikatan antar individu sangat penting, dan juga dapat mencegah ide bunuh diri bagi pasien psikiatri rawat inap. Begitu juga penelitian Campos dan Holden (2015) yang menemukan bahwa persepsi pengabaian (rejection) orangtua secara langsung menjadi faktor resiko bunuh diri remaja dan dewasa. Dengan kata lain, hubungan sosial yang hangat dan positif dengan lingkungan sosial mampu menjadi faktor protektif untuk remaja bunuh diri (Kwak \& Ickovics, 2019). Kehadiran dan kepedulian dari orang lain yang signifikan sangat dibutuhkan semua orang untuk mengatasi beban mental. Tingkah laku bunuh diri berawal dari munculnya pemikiran bunuh diri yang mengarah ke mengakhiri hidup diri sendiri. Menurut Miranda dan Shaffer (2013), pada remaja dan dewasa yang memiliki pemikiran untuk bunuh diri akan melakukan percobaan bunuh diri dalam setahun berikutnya. Individu yang menemui kejadian negatif dalam hidupnya yang semakin berat akan semakin kuat memiliki pemikiran bunuh diri dan tindakan bunuh diri (Liu \& Miller, 2014).

\section{Model Kognitif Tingkah Laku Bunuh Diri}

Dengan didasari teori Beck's general cognitive of psychopathology. Beck dan Wenzel (2008) mengembangkan model kognitif untuk menjelaskan tingkah laku bunuh diri pada individu yang bukan pasien psikiatri. Model ini (bagan 1) terdapat tiga bagian utama yaitu, faktor-faktor kecenderungan yang rentan (dispositional vulnerability factors), proses kognitif yang berhubungan dengan gangguan psikiatri (cognitive processes associated with psychiatric disturbance), dan proses kognitif yang berhubungan dengan tindakan bunuh diri (cognitive processes associated with suicidal acts).

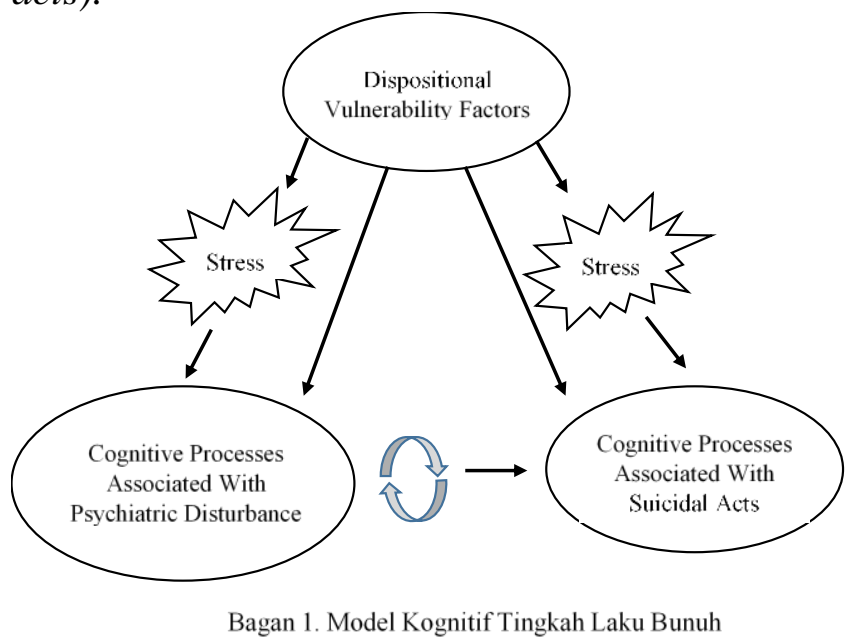

Faktor-faktor kecenderungan yang rentan bersifat menetap dalam diri individu. Faktorfaktor kecenderungan yang rentan antara lain impulsifitas, defisiensi pemecahan masalah, overgeneral memory style (kesulitan mengingat 
kejadian masa lalu yang spesifik), a trait-like maladaptive cognitive style (pola berpikir yang tidak sistematis, tidak fleksibel, dan berlebihan), dan kepribadian (perfectionism dan neuroticism). Pada proses kognitif yang berhubungan dengan gangguan psikiatri terdiri dari konten-konten kognitif yang maladaptif dan bias-bias dalam pengolahan informasi gangguan psikiatri. Sedangkan proses kognitif yang berhubungan dengan tindakan bunuh diri tersusun dari kontenkonten kognitif yang maladaptif dan bias-bias dalam pengolahan informasi pada masa individu mengalami krisis bunuh diri. Tingkat dan jumlah faktor kecenderungan yang rentan menentukan tingkat stres dan mengganggu proses kognisi seseorang untuk mengatasi krisis bunuh diri, sehingga menyebabkan individu mengalami gangguan psikiatri, dan/ berada di situasi krisis untuk bunuh diri. Jika ketiganya tinggi, maka individu kurang dapat menghadapi stress dalam hidupnya dengan baik, begitu pula sebaliknya.

Menurut Wenzel dan Beck (2008) ketika seseorang mengalami stress tambahan, hopelessness memicu proses kognisi yang terkait bunuh diri (bagan 2). Hopelessness ada dua jenis yaitu, state hopelessness dan trait hopelessness. State hopelessness adalah derajat putus asa yang muncul pada satu waktu. State hopelessness adalah tipe konten kognisi yang merefleksikan kesimpulan bahwa situasi individu saat ini tidak dapat ditoleransi dan tidak dapat diubah. Sedangkan trait hopelessness adalah individu memiliki ekspektasi negatif yang menetap terhadap masa depan. Ketika trait ini ketika bertemu dengan sumber stress dari lingkungan, maka dapat meningkatkan derajat state hopelessness. Hal ini karena stress menimbulkan kesimpulan pada kognisi individu bahwa jalan satu-satunya untuk keluar dari masalah yaitu bunuh diri dan mengaktifkan trait hopelessness individu. Hopelessness berpengaruh pada individu yang memiliki riwayat attempt (percobaan bunuh diri) dengan intensi untuk membunuh dirinya sendiri. Tingkat hopelessness dapat meningkat jika stres yang dialami individu sudah tidak dapat ditahan lagi oleh individu.

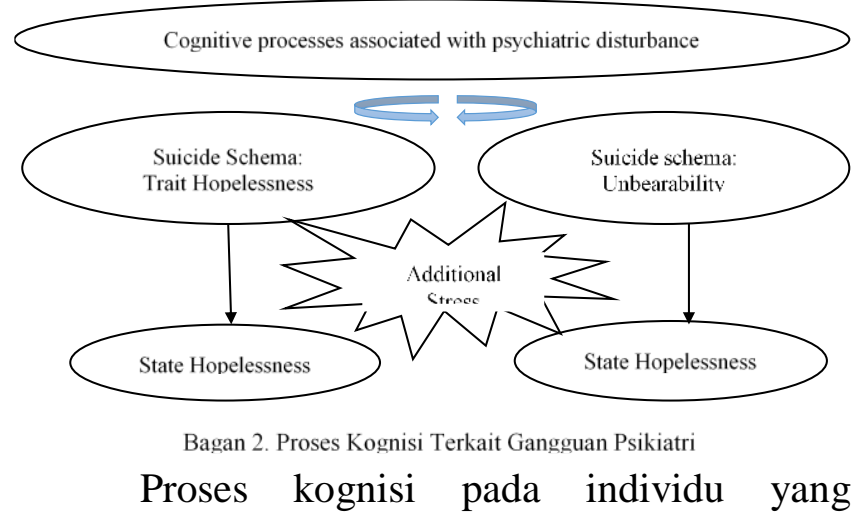
mengalami gangguan psikologis memiliki proses kognisi yang salah, konten kognisi yang negatif, suasana hati negatif, dan tingkah laku negatif. Proses kognisi yang patologis ini dapat memicu proses kognisi untuk bunuh diri dan skema bunuh diri. Di dalam skema bunuh diri terdapat 2 konstruk yaitu trait hopelessness dan unbearability. Unbearability adalah persepsi tak tertahankan ketika sumber stress yang terakumulasi hingga suatu waktu mengakibatkan individu merasa menghadapi hal-hal terkait sumber stres tersebut (Beck \& Wenzel, 2008).

Model kognisi yang memicu individu melakukan bunuh diri yaitu, skema bunuh diri dengan hopelessness kronik dan skema dengan persepsi unbearability (bagan 3). Sedangkan pikiran individu yang terpaku bahwa solusi dari kondisi hidupnya adalah bunuh diri disebut juga dengan attentional fixation atau fiksasi atensi. State hopelessness dan fiksasi atensi saling mempengaruhi. State hopelessness meningkatkan fiksasi atensi dan begitu pula sebaliknya. Fiksasi atensi berisi atensi kognisi yang preokupasi dengan bunuh diri sebagai jalan keluar. Ekspresi emosi dari fiksasi atensi adalah cemas dan agitasi. Fiksasi atensi dan state hopelessness memperburuk kondisi suicide ideation dan menjadi dasar tindakan bunuh diri (kognitif, afektif, dan tingkah laku). Semakin persepsi individu terpaku dengan bunuh diri sebagai solusi, maka semakin hopeless individu dengan kondisi hidupnya atau semakin berpikir bahwa kondisinya tidak tertahankan (Wenzel \& Beck, 2008). 


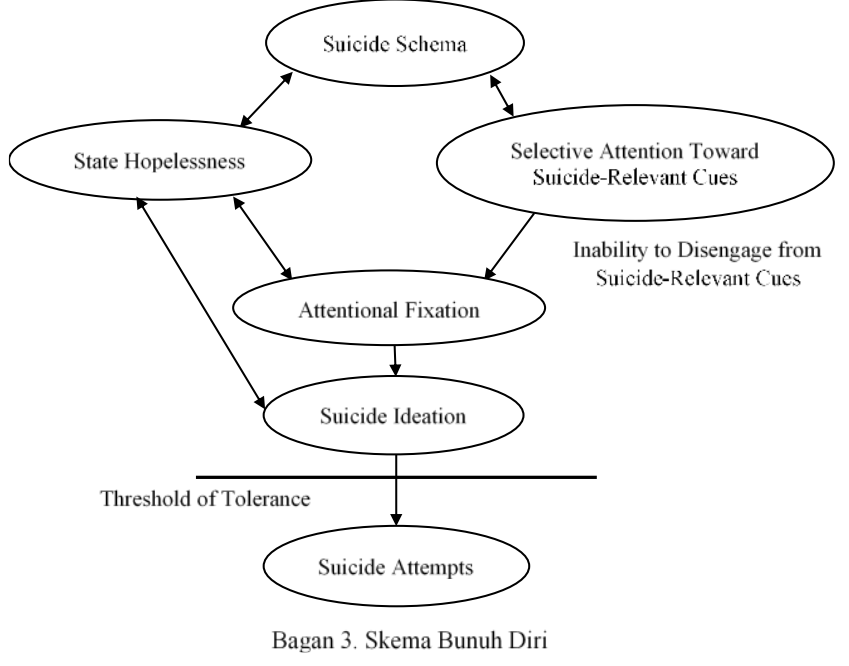

Proses seseorang dari pikiran bunuh diri menjadi tindakan bunuh diri bergantung pada seberapa individu tersebut dapat toleransi dengan stress dari proses kognisi dan emosi yang berlebihan ketika masa krisis ingin bunuh diri, atau disebut juga dengan ambang toleransi (the threshold of tolerance). Ambang toleransi tersebut dipengaruhi oleh pengalaman tingkah laku bunuh diri individu sebelumnya (Beck \& Wenzel, 2008).

\section{METODE}

\section{Variabel dan Definisi Operasional}

Variabel dalam penelitian ini merupakan tematema yang menjadi faktor pemicu ide bunuh diri. Ide bunuh diri adalah pikiran yang muncul sewaktu-waktu untuk mengahiri hidup sendiri dengan atau tanpa rencana spesifik.

\section{Responden}

Kriteria partisipan yang dalam penelitian ini yaitu mahasiswa berusia 17-23 tahun, warga Negara Indonesia, mahasiswa aktif program sarjana, sedang menjalani kuliah di Universitas Padjadjaran, pernah berpikir untuk bunuh diri setidaknya satu kali (dan atau pernah melakukan percobaan bunuh diri) dalam waktu seminggu terakhir, dan bersedia menjadi partisipan penelitian ini.

\section{Tempat Penelitian}

Penelitian dilakukan pada bulan Mei 2019 dengan bertemu langsung dalam ruangan kelas yang sedang tidak digunakan di Fakultas Psikologi Universitas Padjadjaran. Pertemuan dilakukan berdasarkan kesepakatan bersama dan ketersediaan ruangan.

\section{Prosedur Penelitian}

Peneliti menyiapkan susunan pertanyaan dengan menggunakan kerangka Model Tingkah Laku Bunuh Diri Beck dalam bentuk pertanyaan terbuka, beserta lembar kesediaan partisipan. Kemudian peneliti menyebarkan pengumuman melalui media sosial dan individu yang bersedia menjadi partisipan akan menanyakan identitasnya untuk mendapatkan partisipan yang sesuai kriteria. Partisipan kemudian membuat janji pertemuan dengan peneliti.

Pada saat wawancara, peneliti menjelaskan terlebih dahulu identitas peneliti, tujuan penelitian, kerahasiaan data, resiko yang mungkin akan diperoleh partisipan, durasi, kegiatan yang akan dilakukan, dan nomor lembaga konseling psikolog jika sewaktu-waktu diperlukan oleh partisipan. Wawancara dilakukan bersamaan dengan observasi. Selama wawancara data yang diperoleh dicatat oleh peneliti. Di akhir wawancara partisipan diberi kupon makan sebesar Rp 20.000,untuk sekali makan dan diberi ucapan terimakasih.

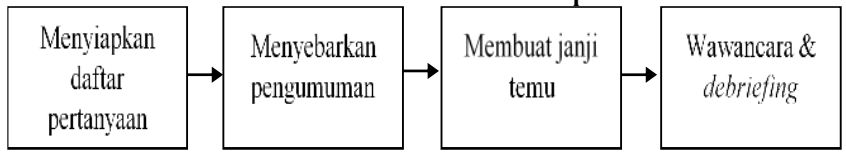

Bagan 4. Skema Pengambilan Data Penelitian

\section{Data Pendahuluan}

Dikarenakan belum banyak penelitian faktor resiko tingkah laku bunuh diri pada mahasiswa terutama di Indonesia, maka peneliti mencoba menggali gambaran tingkah laku bunuh diri di lingkungan mahasiswa. Pengambilan data awal melalui teknik wawancara terhadap tiga orang narasumber. Wawancara dilakukan dengan telepon. Teknik sampling partisipan menggunakan snow ball. Wawancara berlangsung kurang lebih dua jam dalam satu kali kontak. Wawancara mengikuti model tingkah laku (Beck \& Wenzel, 2008) dengan menggunakan pertanyaannya terbuka. Data yang diperoleh dikelompokkan berdasarkan tema-tema yang muncul dan kesamaan tema dari ketiga partisipan. Serta, dari data tersebut dipelajari mekanisme tingkah laku bunuh diri tersebut. 


\section{Teknik Analisis Data}

Data dianalisis dengan berfokus pada isu kunci atau tema-tema pada setiap kasus untuk memahami kompleksitas kasus atau disebut within case analysis. Kemudian dilakukan analisis kesamaan tema antar kasus (disebut cross-cases analysis). Serta dilakukan assertion yaitu menginterpretasikan makna dari kasus, dan seluruh kasus (Creswell, 2007).

\section{HASIL}

Dari tiga kasus tingkah laku bunuh diri menurut Model Tingkah Laku Bunuh Diri (Wenzel \& Beck, 2008), terdapat beberapa kesamaan dan perbedaan tema-tema yang dialami partisipan hingga memunculkan pemikiran bunuh diri. Faktor resiko yang menyebabkan individu ingin bunuh diri atau disebut faktor-faktor kecenderungan yang rentan. Ketiga kasus memiliki faktor kondisi kerentanan psikologis masing-masing, seperti kecemasan yang berlebih dan depresi yang menetap. Secara langsung maupun tidak faktor-faktor kecenderungan yang rentan ini mempengaruhi proses kognisi individu dalam menghadapi sumber stres.

Sumber stres berat yang mengawali proses berpikir yang maladaptif dan berujung dengan kesimpulan tindakan bunuh diri yaitu pengalaman diabaikan oleh orang lain pada ketiga kasus. Bentuk penolakan berupa perhatian yang lebih ibu kepada saudara kandung, kekerasan verbal, dan kekerasan fisik di masa kecil. Kondisi anggota keluarga yang berpisah karena perceraian atau tuntutan pekerjaan juga menjadi sumber stres yang memperburuk persepsi partisipan terhadap pengalaman penolakan yang dialami. Hal ini disebabkan oleh proses kognisi terkait gangguan psikiatri atau proses kognisi yang mengandung bias. Bias muncul dalam bentuk generalisasi pengalaman penolakan secara berlebihan. Persepsi bahwa diri diabaikan memunculkan pikiran bahwa semua orang akan menolak diri saya, saya akan disakiti oleh semua orang, dan hanya prestasi akademis yang bagus satu-satunya jalan untuk diterima oleh orang-orang yang signifikan bagi partisipan, terutama ibu.
Prestasi akademis menjadi fokus yang dinilai sangat berharga bagi partisipan. Jika prestasi yang diharapkan tidak dapat diraih atau ada kemungkinan akan mendapat nilai jelek, maka kondisi ini ditambah proses kognisi yang maladaptif menyebabkan partisipan mengambil kesimpulan yang bias. Kesimpulan bahwa lebih baik mati daripada mendapat nilai jelek. Proses kognisi yang terkait gangguan psikiatri ini berubah menjadi proses kognisi yang berujung tindakan bunuh diri. Hal ini karena secara tidak disadari, partisipan menyamakan bahwa nilai baik akan diterima atau mendapat perhatian, sedangkan nilai buruk akan diabaikan atau tidak diperhatikan.

Ketika mendapatkan tekanan lagi dari sumber stres lain yang serupa dan diolah dengan proses kognisi terkait gangguan psikiatri atau maladaptif akan memicu state hopelessness. Tambahan stres yang serupa lebih sensitif bagi partisipan, seperti pengalaman kekerasan kembali oleh atasan yang dipersepsi menyerupai perlakukan kasar ibu, menimbulkan dampak psikologis yang serupa dan juga menimbulkan ide untuk bunuh diri kembali. State hopelessness berupa kesimpulan putus asa terhadap prestasi akademis selama ini atau seluruh aspek kehidupan partisipan. Selain putus asa, ada pula fiksasi atensi yang dominan dan berulang seperti kecenderungan pola berpikir yang digunakan untuk semua permasalahan.

Atensi partisipan pada setiap kasus terfokus pada tanda-tanda yang serupa dengan sumber stres terbesarnya yang menyebabkan munculkan ide jalan keluar berupa bunuh diri. Pada kasus partisipan yang merasa kurang mendapat perhatian atau diabaikan oleh ibu, partisipan terfokus atensinya dan sensitif pada perhatian dari orang lain. Jika ada penolakan dari orang lain (seperti dosen menolak usulan skripsi), maka partisipan merasa bahwa penolakan tersebut adalah penolakan terhadap diri partisipan. Partisipan seolah-olah tidak dapat melepaskan pikirannya dari tanda-tanda sumber stres tersebut. Partisipan dengan riwayat kekerasan verbal kesulitan untuk tidak terpicu untuk bunuh diri oleh 
teguran keras dari atasan. Tambahan stres malah memperburuk persepsi individu terhadap permasalahannya dan meningkatkan intensi untuk bunuh diri. Semakin sering tambahan stres dialami, maka semakin sering dan kuat intensitas untuk bunuh diri pada ketiga partisipan.

Kondisi individu yang kurang mampu berpikir dengan adaptif terhadap masalah yang dihadapi menimbulkan ide bunuh diri atau suicide ideation. Ide bunuh diri muncul ketika individu sedang berada di tempat yang terisolasi dari lingkungan sosialnya, seperti kamar indekos. Waktu kemunculannya berbeda-beda setiap orang. Hanya saja intensitas ide tersebut konsisten tinggi pada ketiga partisipan, antara 7 hingga 9 dari skala 10. Durasi setiap partisipan juga berbeda, antara sesaat hingga satu minggu. Ide bunuh diri juga terpengaruhi oleh kondisi fisik, seperti beberapa hari sebelum menstruasi partisipan menjadi lebih sensitif.

Ide bunuh diri tidak secara langsung dilakukan menjadi percobaan bunuh diri. Ambang toleransi terhadap stres menentukan ide tersebut akan dilakukan atau tidak. Di dalam toleransi ini terjadi konflik secara kognisi antara beban stres yang dimiliki dengan persepsi diri diterima oleh orang lain atau harapan positif mengenai masa depan. Seperti harapan bahwa masa depan akan lebih baik dari masa sekarang atau ketika cita-cita tercapai kondisi akan membaik. Bertambahnya pengetahuan partisipan bahwa semua orang memiliki masalah dan sama-sama merasa berat untuk melewati masalah tersebut dapat meningkatkan toleransi partisipan terhadap stres. Serta menurunkan intensitas ide bunuh diri. Jika toleransi rendah terhadap stres, maka kondisi psikologis partisipan akan memburuk dan begitu sebaliknya.

Dari ketiga kasus ditemukan kesamaan riwayat self-harm yang dilakukan untuk menghadapi sumber stres. Terkadang ide selfharm juga diiringi keinginan untuk membunuh diri sendiri. Tingkah laku menyakiti ini muncul dan berlangsung kurang lebih sejak munculnya ide bunuh diri hingga saat wawancara dilakukan. Intensi untuk menyakiti diri juga terasa sama kuat dengan intensi ide bunuh diri. Selain melakukan self-harm untuk menghadapi masalah, partisipan juga menggunakan strategi coping lainnya. Strategi lainnya yang dilakukan kurang efektif untuk menurunkan intensi partisipan untuk bunuh diri, malah memperburuk kondisi psikologis partisipan. Seperti dengan mengurung diri di kamar dan melihat posting teman dan kerabat di media sosial menambah persepsi bahwa hidup semua orang baik saja dan hanya hidup saya yang tidak berguna.

Kebetulan ketiga partisipan mengetahui layanan penanganan mental, para partisipan paham bahwa terkadang stres yang dialami perlu bantuan tenaga profesional untuk meringankan beban stres. Ketiga partisipan memiliki perbedaan layanan yang digunakan, yaitu psikiater, psikolog, dan layanan konseling online melalui aplikasi. Tenaga penanganan mental yang menunjukkan kehangatan juga membantu memberikan harapan kepada kliennya untuk meneruskan hidupnya.

Pelopor utama ide bunuh diri adalah proses kognitif yang maladaptif (Flink, Lehto, Koivumaa-Honkanen, Viinamaki, Ruusunen, Valkonen-Korhonen, Honkalampi, 2017). Disebut maladaptif karena adanya bias kognitif yang muncul dalam bentuk generalisasi terhadap pengalaman penolakan. Generalisasi bahwa setiap tindakan di masa depan akan membawa dampak penolakan yang serupa dengan masa lalu. Pada penelitian ini yang berfous pada mahasiswa, prestasi menjadi kunci penerimaan dari orangtua terutama kebutuhan penerimaan dari figur ibu. Dengan kata lain, besaran prestasi yang diraih menentukan diri mahasiswa diterima oleh ibu atau tidak. Persepsi terfokus hanya pada itu, sedangkan tingkah laku positif lain tidak disadari menjadi ukuran diri dinilai baik atau tidak oleh orang lain. Seperti sikap yang santun, penurut, rajin, atau periang. Hal-hal terkait nilai atau prestasi sangat mudah mempengaruhi mahasiswa dan memicu kecemasan.

Temuan penelitian ini bahwa mahasiswa yang pernah mengalami kekerasan verbal maupun fisik di masa kecil memicu keinginan mengakhiri diri sendiri dikemudian hari. Temuan ini sejalan 
dengan dengan temuan Bahk, Jang, Choi, dan Lee (2017) bahwa berbagai bentuk perlakuan terhadap anak yang kurang tepat terutama kekerasan seksual memicu ide bunuh diri anak. Termasuk kekerasan dalam keluarga sudah jelas menjadi salah satu memicu ide bunuh diri anak. Tetapi di penelitian ini ditemukan juga persepsi diabaikan atau kurangnya perhatian pada anak sebab adanya kondisi kesehatan yang buruk pada anak yang lain dapat menimbulkan pemikiran bahwa diri tidak dicintai atau ditolak. Kondisi keluarga lainnya yang menjadi faktor resiko adalah perpisahan orangtua. Baik perpisahan karena perceraian, maupun kondisi pekerjaan. Hal ini dikarenakan pada anak-anak dengan orangtua yang berpisah mengalami masalah gangguan emosional $(\mathrm{Fu}$, Xue, Zhou, Yuan, 2017) atau memiliki kondisi mental yang buruk (Auersperga, Vlasakb, Ponocnyc, Barth, 2019), sehingga mudah berpikir untuk mengakhiri beban psikis yang dirasa dengan meninggalkan dunia ini.

Tingkatan toleransi mahasiswa dapat menjadi baik jika memiliki harapan yang positif terhadap masa depan. Contohnya ketika berpikir saat dapat sukses dengan tercapainya cita-cita kondisi akan membaik. Hal ini disebabkan karena orientasi pada masa depan yang negatif menunjukkan rasa putus asa seseorang (Flink dkk, 2017), dan sebaliknya orientasi yang positif menimbulkan rasa adanya harapan. Toleransi stress mahasiswa dapat membesar jika mendapat pemahaman bahwa banyak orang selain dirinya juga mengalami masalah yang berat. Sebaliknya saat melihat media sosial yang biasanya hanya berisi hal baik dari lingkungan sekitar dapat menyebabkan individu merasa hanya hidupnya yang tidak bahagia. Penggunaan media sosial juga dapat memperburuk kondisi mental mahasiswa jika unggahan yang dilihat dipersepsi dengan negatif.

\section{KESIMPULAN}

Temuan penelitian ini menunjukkan bahwa tingkah laku bunuh diri merupakan hasil proses kognitif yang tidak cukup adaptif dalam mengelolah stres. Selain itu, adanya kondisi partisipan mengalami sumber stres tambahan yang serupa dengan sumber stres utama terkait bunuh diri. Stres yang memicu bunuh diri yaitu stres akibat pengalaman diabaikan atau disakiti. Ambang toleransi partisipan terhadap stres dan tambahan stres dapat meningkat jika partisipan memiliki motivasi yang cukup tinggi untuk mencapai cita-cita atau partisipan optimis bahwa masa depannya akan lebih baik dari masa sekarang. Serta, adanya riwayat self-harm yang menjadi cara partisipan menanggulangi terhadap stres yang dihadapi.

\section{SARAN}

Penelitian ini terbatas pada partisipan perempuan, belum dilakukan wawancara dengan partisipan laki-laki. Mungkin akan ada perbedaan hasil karena perbedaan jenis kelamin partisipan yang terlibat. Serta, partisipan yang terlibat tidak memiliki riwayat suicide attempt berulang kali, sehingga butuh penelitian lebih lanjut untuk memahami proses kognisi suicide ideation berubah menjadi suicide attempt.

\section{UCAPAN TERIMA KASIH}

Terimakasih saya ucapkan kepada Bapak Dr. Zainal Abidin, M. Si. atas bimbingan dan arahannya dalam penelitian ini.

\section{DAFTAR PUSTAKA}

Auersperga, F., Vlasakb, T., Ponocnyc, I., \& Barth, A. (2019). Long-term effects of parental divorce on mental health - a meta-analysis. Journal of Psychiatric Research, 119, 107-115. doi: 10.1016/j.jpsychires.2019.09.011

Bahk, Y. C., Jang, S. K., Choi, K. K., \& Lee, S. H., (2017). The relationship between childhood trauma anda suicidal ideation: role of maltreatment and potential mediators. Korean Neuropsychiatric Association, 14(1), 37-43. doi: 10.4306/pi.2017.14.1.37

Brown, S. L., Mitchell, S. M., Rousch, J. F., Rosa, N. I. L., \& Cukrowicz, K. C. (2019). Rejection sensitivity and suicide ideation 
among psychiatric inpatients: an integration of two theoretical models. Psychiatry Research, 272, 54-60.

Campos, R. C., \& Holden, R. R. (2015). Testing models relating rejection, depression, interpersonal needs, and psychache to suicide risk in nonclinical individuals. Journal of Clinical Psychology, 71(10), 994-1003. doi: 10.1002/jclp.22196

Creswell, J. W. (2007). Qualitative Inquiry \& Research Design $2^{\text {nd }}$. New York: Sage Publications.

Flink, N., Lehto, S. M., Koivumaa-Honkanen, H., Viinamaki, H., Ruusunen, A., ValkonenKorhonen, M., \& Honkalampi, K. (2017). Early maladaptive schemas and suicidal ideation in depressed patients. The European Journal of Psychiatry, 31(3), 87-92. doi: 10.1016/j.ejpsy.2017.07.001

Fu, M., Xue, Y., Zhou, W., \& Yuan, T. F. (2017). Parental absence predicts suicide ideation through emotional disorders. PLoS ONE (12) $12, \quad 1-10 . \quad$ doi: 10.1371/journal.pone.0188823

Kwak, C. W., \& Ickovics, J. R. (2019). Adolescent suicide in south korea: risk factors and proposed multi-dimensional solution. Asian Journal of Psychiatry, 43, 150-153. doi: 10.1016/j.ajp.2019.05.027

Liu, R. T., \& Miller, I. (2014). Life event and suicidal ideation and behavior: a systematic review. Clinical Psychology Review, 34, 181-192. doi: 10.1016/j.cpr.2014.01.006

Miranda, R., \& Shaffer, D. (2013). Understanding the suicidal moment in adolescence. Childhood Onset Development Disorder, 14-21. doi:10.1111/nyas.12291

Wenzel, A., \& Beck, A.T. (2008). A cognitive model of suicidal behavior: theory and treatment. Applied and preventive Psychology, 12, 189-201. doi:10.1016/j.appsy.2008.05.001

World Health Organization. (2015). Mental Health. Diakses dari http://www.who.int/mental_health/preve ntion/suicide/suicideprevent/en/ 